\title{
ISONIAZID-RESISTANT MYCOBACTERIUM TUBERCULOSIS: PREVALENCE, RESISTANCE SPECTRUM AND GENETIC DETERMINANTS OF RESISTANCE
}

\author{
Andreevskaya SN $\bowtie$, Smirnova TG, Larionova EE, Andrievskaya IYu, Chernousova LN, Ergeshov A
}

Central Tuberculosis Research Institute, Moscow, Russia

\begin{abstract}
The lack of simple, rapid diagnostic tests for isoniazid-resistant rifampicin-susceptible tuberculosis infection (Hr-TB) can result in low treatment efficacy and further amplification of drug resistance. Based on the clinical data, this study sought to estimate the prevalence of Hr-TB in the general population and characterize the phenotypic susceptibility and genetic determinants of isoniazid resistance in M. tuberculosis strains. Molecular-genetic and culture-based drug susceptibility tests were performed on $M$. tuberculosis isolates and $M$. tuberculosis DNA obtained from the patients with pulmonary TB undergoing treatment at the Central Tuberculosis Research Institute between 2011 and 2018. The tests revealed that $\mathrm{Hr}$-TB accounted for 12\% of all TB cases in the studied sample. Hr-TB strains were either resistant to isoniazid only (45\%) or had multiple resistance to 2-6 anti-TB agents. Resistance to isoniazid was caused by mutations in the katG gene. Based on the literature analysis and our own observations, we emphasize the importance of developing simple molecular drug susceptibility tests capable of detecting simultaneous resistance to rifampicin and isoniazid and the necessity of their translation into clinical practice.
\end{abstract}

Keywords: M. tuberculosis, isoniazid resistance, drug susceptibility, molecular diagnostics, single nucleotide polymorphism, tuberculosis

Funding: this study was supported by the Ministry of Science and Higher Education of the Russian Federation and carried out under the Federal Targeted Program for Research and Development in Priority Areas of Development of the Russian Scientific and Technological Complex for 2014-2020, Project № 05.586.21.0065 (Project ID RFMEFI58619X0065).

Author contribution: Ergeshov A, Chernousova LN — study design; Larionova EE, Andrievskaya IYu — data acquisition; Smirnova TG — data analysis; Andreevskaya SN - manuscript preparation, literature analysis. All authors have equally contributed to the discussion of the obtained results.

Compliance with ethical standards: we retrospectively analyzed the results of routine laboratory tests performed on the patients undergoing treatment for tuberculosis at the Central Tuberculosis Research Institute. All patients gave informed consent.

$\square$ Correspondence should be addressed: Sofya N. Andreevskaya

Yauzskaya alley, 2, Moscow, 107564; andsofia@mail.ru

Received: 11.12.2019 Accepted: 07.01.2020 Published online: 12.01.2020

DOI: $10.24075 /$ brsmu.2020.001

\section{ИЗОНИАЗИД-РЕЗИСТЕНТНЫЕ MYCOВАCTЕRIUM TUBERCULOSIS: ЧАСТОТА ВЫЯВЛЕНИЯ, СПЕКТРЫ РЕЗИСТЕНТНОСТИ И ГЕНЕТИЧЕСКИЕ ДЕТЕРМИНАНТЫ УСТОЙЧИВОСТИ}

\author{
С. Н. Андреевская $₫$, Т. Г. Смирнова, Е. Е. Ларионова, И. Ю. Андриевская, Л. Н. Черноусова, А. Эргешов
}

Центральный научно-исследовательский институт туберкулеза, Москва, Россия

\begin{abstract}
Отсутствие ускоренной диагностики туберкулеза с устойчивостью возбудителя к изониазиду с сохраненной чувствительностью к рифампицину (ИРТБ) может быть причиной низкой эффективности терапии и приводить к амплификации лекарственной резистентности, в том числе к формированию множественной лекарственной устойчивости. Целью работы было определить частоту встречаемости ИР-ТБ в современной популяции, охарактеризовать фенотипическую чувствительность и генетические детерминанты устойчивости к изониазиду представителей этой группы M. tuberculosis на репрезентативном материале. Анализировали результаты определения лекарственной чувствительности, полученные при исследовании молекулярногенетическими и/или культуральными методами изолятов M. tuberculosis / ДНК M. tuberculosis, выделенных от больных туберкулезом легких из клинических отделений Центрального научно-исследовательского институа туберкулеза за период 2011-2018 гг. Частота ИР-ТБ составила 12\% от всех выявленных случаев туберкулеза. M. tuberculosis с ИР были как монорезистентными к изониазиду (45\%), так и полирезистентными (устойчивыми к 2-6 противотуберкулезным препаратам), а устойчивость к изониазиду была обусловлена мутациями в гене katG, приводящими к высокому уровню резистентности. На основании анализа литературных данных и собственных наблюдений подчеркивается важность разработки и внедрения новых простых молекулярных тестов для определения устойчивости одновременно к рифампицину и изониазиду.
\end{abstract}

Ключевые слова: M. tuberculosis, изониазид-резистентность, лекарственная чувствительность, молекулярная диагностика, однонуклеотидный полиморфизм, туберкулез

Финансирование: работа выполнена при финансовой поддержке Министерства науки и высшего образования Российской Федерации в рамках Федеральной целевой программы «Исследования и разработки по приоритетным направлениям развития научно-технологического комплекса России на 2014-2020 годы», соглашение № 05.586.21.0065 (уникальный идентификатор соглашения RFMEFI58619X0065).

Вклад авторов: А. Эргешев, Л. Н. Черноусова - разработка дизайна исследования; Е. Е. Ларионова, И. Ю. Андриевская - получение данных для анализа; Т. Г. Смирнова - анализ полученных данных; С. Н. Андреевская - написание текста рукописи, обзор публикаций по теме статьи; все авторы участвовали в обсуждении результатов.

Соблюдение этических стандартов: был проведен ретроспективный анализ результатов, полученных при выполнении рутинных лабораторных исследований для пациентов, проходящих лечение в Центральном НИИ туберкулеза; все пациенты подписали добровольное информированное согласие на проведение исследования.

$\triangle$ Для корреспонденции: Софья Николаевна Андреевская

Яузская аллея, д. 2, г. Москва, 107564; andsofia@mail.ru

Статья получена: 11.12.2019 Статья принята к печати: 07.01.2020 Опубликована онлайн: 12.01.2020

DOI: $10.24075 /$ vrgmu.2020.001

Drug-resistant tuberculosis (TB) is a serious public health concern. At present, the major focus is on fighting multidrugresistant TB (MDR-TB), i.e. caused by strains resistant to at least 2 most effective anti-TB drugs: isoniazid and rifampicin
[1]. Russia has the third-highest burden of MDR-TB [2]. In 2018, the incidence and prevalence of MDR-TB in Russia stabilized at 5.6 and 23.6 cases per 100, 000 population, respectively. However, the share of patients with MDR-TB among individuals 
with active TB disease increased both in terms of incident cases (from $27.4 \%$ in 2017 to $29.3 \%$ in 2018) and the total respiratory TB burden (from 54.0\% in 2017 to 55.3\% in 2018) [3].

By contrast, other forms of drug-resistant TB are receiving less attention, including isoniazid-resistant TB ( $\mathrm{Hr}-\mathrm{TB})$ assigned to a separate category by $\mathrm{WHO}$. Its causative agent is resistant to isoniazid but sensitive to rifampicin [4]. Isoniazid is a firstline drug that exerts a bactericidal effect on $M$. tuberculosis and is highly effective in treating active TB forms. Phenotypic resistance to isoniazid is associated with mutations in katG, $\operatorname{inh} A$, ahpC and some other genes that encode proteins involved in the pharmacokinetics and pharmacodynamics of isoniazid in the bacterial cell $[5,6]$.

Inadequate therapy for $\mathrm{Hr}$-TB promotes a high risk of acquiring resistance to other anti-TB drugs, including rifampicin, and results in MDR [7]. According to $\mathrm{WHO}, \mathrm{Hr}$-TB prevalence varies from 5 to $11 \%$ across $\mathrm{WHO}$ regions [8]. The data on $\mathrm{Hr}$ TB prevalence in Russia is scarce.

This study aimed to estimate the prevalence of isoniazidresistant $M$. tuberculosis in patients presenting with pulmonary TB at the clinical departments of Central Tuberculosis Research Institute between 2011 and 2018, as well as to provide an extensive phenotypic drug sensitivity profile and describe genetic determinants of resistance to isoniazid in this group of M. tuberculosis isolates.

\section{METHODS}

\section{Object of research}

In this study, we looked at M. tuberculosis isolates and/or DNA isolated from the clinical specimens collected from the patients with pulmonary TB who had presented at the counselling and clinical departments of Central Tuberculosis Research Institute in 2011-2018. All microbiological tests were performed on the same sample.

\section{Culture tests}

The cultures were grown and analyzed for the presence of M. tuberculosis in a Middlebrook $7 \mathrm{H} 9$ broth base in a BACTEC MGIT 960 system (BD; USA) following the manufacturer's protocol [9]. For drug susceptibility testing, we used BACTEC MGIT 960 instrumentation (BD; USA) and a modified proportion method. The isolates were tested for sensitivity to 8 drugs taken at critical concentrations, including isoniazid $(\mathrm{H}, 0.1 \mu \mathrm{g} / \mathrm{ml})$, rifampicin $(R, 1.0 \mu \mathrm{g} / \mathrm{ml})$, ethambutol ( $E, 5.0 \mu \mathrm{g} / \mathrm{ml})$, pyrazinamide (Z, $100.0 \mu \mathrm{g} / \mathrm{ml}$ ), ethionamide (Eto, $5,0 \mu \mathrm{g} / \mathrm{ml}$ ), amikacin (Am, $1.0 \mu \mathrm{g} / \mathrm{ml})$, capreomycin $(\mathrm{Cm} 2.5 \mu \mathrm{g} / \mathrm{ml})$, and levofloxacin (Lfx, $1.0 \mu \mathrm{g} / \mathrm{ml})$. Standard protocols were applied $[9,10]$.

\section{DNA isolation}

DNA was isolated from the clinical specimens using an Amplitub-RV reagent kit 1 for the isolation, detection and quantification of mycobacterial DNA by real-time PCR (Syntol; Russia) following the manufacturer's protocol.

Detection of $M$. tuberculosis DNA was performed using an Amplitub-RV reagent kit 2 for the isolation, detection and quantification of mycobacterial DNA by real-time PCR (Syntol; Russia) following the manufacturer's protocol. DNA fragments were amplified in a thermocycler equipped with a CFX96 optical reaction module (Bio-Rad; USA).

Genotypic resistance to rifampicin, isoniazid and fluoroquinolones was tested using either TB-Biochip-1 and
TB-Biochip-2 kits that utilize a microarray technology (BiochipIMB; Russia) or Amplitub-MDR-RV and Amplitub-FQ-RV kits (Syntol; Russia). All procedures were carried out in compliance with the manufacturers' guidelines.

\section{Statistical analysis}

Descriptive statistics were used to analyze the results of the study, including the number of observations, frequencies, percentages, and 95\% Cl. The analysis was conducted in MS Excel (Microsoft; USA).

\section{RESULTS}

Clinical specimens collected from 4056 patients with pulmonary TB were subjected to culture-based and molecular testing. In 71 cases, neither $M$. tuberculosis DNA nor tubercle bacilli themselves were detected; so those cases were excluded from the analysis. Phenotypic/genotypic drug susceptibility was determined for $M$. tuberculosis DNA/cultures isolated from the remaining 3985 samples. If the results of culture tests contradicted those of molecular tests, priority was given to culture-based data (Table 1). For example, 38 strains that demonstrated resistance to both isoniazid and rifampicin in culture tests but had no mutations in the rpoB gene implicated in rifampicin resistance were put into the MDR category because molecular rifampicin susceptibility tests used in our study could only detect a limited number of mutations, meaning that genetic determinants of rifampicin resistance might have been overlooked in the analysis. And, vice versa, 29 strains that tested positive for mutations in the rpoB gene and did not have the rifampicin-resistant phenotype were categorized as isoniazid-resistant.

The total sample of drug-resistant $M$. tuberculosis strains was dominated by MDR isolates (Table 1). However, isoniazidresistant strains that were susceptible to rifampicin were also well represented in the sample (502/3985; 12.60\%).

The analysis of clinical data over the period from 2011 to 2018 revealed that $\mathrm{Hr}$-TB amounted to about $14 \%$ of all TB cases per year reported in 2011-2012 and 2017-2018. In 2013-2016, the rate of detection for this TB form was lower (10-11\%). We were unable to describe this linear trend with a sufficient degree of reliability (Table 2).

Because culture-based tests are less sensitive than molecular methods, the growth of $M$. tuberculosis in culture media was not detected for some specimens. Therefore, phenotypic sensitivity to anti-TB drugs was only determined for 260 isoniazid-resistant isolates of $M$. tuberculosis (Table 3). The following definitions were applied to identify the type of drug resistance of $M$. tuberculosis isolates [1]: monoresistance, i.e. resistance of the mycobacterium to only one anti-TB drug, and polyresistance, i.e. resistance of the mycobacterium to 2 or more anti-TB drugs but not to the combination of isoniazid and rifampicin.

Monoresistant isolates amounted to $117 / 260$ (45\%) cases. The rest 143 (55\%) isolates were polyresistant (to 2-6 drugs). Polyresistant isolates were equally represented by $M$. tuberculosis strains resistant to both isoniazid and first-line drugs $(42 / 143 ; 29.37 \%)$ and by the strains resistant to both isoniazid and second-line drugs (38/143; 26.57\%); resistance to second-line drugs almost always included resistance to ethionamide (31/38; 81.58\%). Co-resistance to first- and second-line drugs was the most common among the polyresistant isolates (63/143; 44.06\%). Of them, co-resistance to isoniazid, ethambutol and ethionamide (HEEto), including 
their combinations with other second-line medications, was detected in 20/63 (31.75\%) cases; polyresistance to isoniazid, pyrazinamide and ethionamide (HZEto), including their combinations with other second-line drugs, was not so common (9/63 cases or $14.29 \%)$. Polyresistance to HEZEto was observed in 15/63 (23.81\%) isolates. In 19/63 (30,16\%) isolates, resistance spectra included other combinations of drugs (a total of 12 resistance spectra with 3 to 5 drugs).

Data on mutations in the genes associated with resistance to isoniazid were acquired for $451 \mathrm{M}$. tuberculosis isolates resistant to isoniazid (Table 4). In most cases (386/451 isolates or $85.59 \%$ ), single nucleotide polymorphisms (SNPs) were detected in one of the genes associated with resistance to isoniazid. The presence of SNPs in 2 genes associated with isoniazid resistance was not so common (65/451 cases or $14.41 \%)$. The most prevalent were mutations at codon 315 of the katG gene (413/451 cases or $91.57 \%)$. In $348 / 413$ $(84.26 \%)$ cases, mutations were detected only in katG; in $62 / 413(15.01 \%)$ isolates, mutations in katG co-occurred with SNPs in the inhA gene. In single cases, katG mutations cooccurred with SNPs in the ahpC gene.

The inhA15_C->T substitution was quite common (94/451; $20.84 \%)$; in $33 / 94$ (35.11\%) cases it was the only mutation detected. In other samples, this mutation co-occurred with an SNP at codon 315 of the katG gene.

For 209 isolates of $M$. tuberculosis with phenotypically confirmed resistance to isoniazid, the following distribution of mutant variants was observed: 152/209 (72.73\%) carried a mutation in the katG gene only (315_Ser->Thr(1)); 32/209 (15.31\%) carried a combination of katG315_Ser->Thr(1) and inhA15_C->T; 17/209 (8.13\%) only inhA15_C->T was detected. The remaining 8 (3.83\%) isolates with phenotypically confirmed resistance to isoniazid had mutations in other regions of the genes associated with isoniazid resistance (ahpC10_C->T in

Table 1. M. tuberculosis isolates and drug susceptibility tests the absence of other mutations, katG315_Ser->Asn; co-occurring katG315_Ser->Gly + inhA15_C->T, katG315_Ser->Thr(1) + inhA8_T->G, katG315_Ser->Thr(1) + ahpC10_C->T).

Thus, our sample of isoniazid-resistant $M$. tuberculosis was dominated by the katG315_Ser->Thr(1) mutation corresponding to the substitution AGC->ACC (333/451; 73.84\%), followed by the co-occurring katG315_Ser->Thr(1) + inhA15_C->T (60/451; 13.30\%), and single inhA15_C->T (33/451; 7.32\%). On the whole, these 3 mutant variants amounted to 426/451 (94.46\%) isoniazid-resistant M. tuberculosis isolates.

\section{DISCUSSION}

We attempted to estimate the prevalence of isoniazid-resistant, rifampicin-susceptible $M$. tuberculosis strains isolated from the patients with pulmonary TB, who had presented at clinical departments of Central Tuberculosis Research Institute in 2011-2018.

The prevalence of this TB form and the rate of its spread vary across the world's regions. For example, the analysis of data on drug susceptibility collected by WHO from 131 specialized healthcare institutions in 1994-2009 reveals that Eastern Europe had the highest burden of $\mathrm{Hr}$-TB (15\%), followed by Western and Central Europe (11\%); in other WHO regions, $\mathrm{Hr}$-TB prevalence did not exceed 8\% [11]. In some regions, the prevalence of Hr-TB tended to decrease, whereas in others, it was increasing. No clear linear dynamics were established for the majority of $\mathrm{WHO}$ regions. In our study, the prevalence of isoniazid-resistant $M$. tuberculosis (12\%) was similar to that in Eastern Europe and its dynamics were non-linear, just like in the majority of the world's regions.

The systematic review of the link between primary resistance to isoniazid and the acquisition of secondary resistance to other anti-TB drugs [12] concludes that monoresistant strains acquire

\begin{tabular}{|l|c|c|c|c|c|}
\hline \multirow{2}{*}{$\begin{array}{l}\text { Types of sensitivity to } \\
\text { antituberculous drugs }\end{array}$} & \multicolumn{3}{|c|}{$\begin{array}{c}\text { Number of isolates for which data on drug sensitivity } \\
\text { was obtained (abs.) }\end{array}$} & $\begin{array}{c}\text { The total number of } M \text {. tuberculosis isolates assigned to } \\
\text { each sensitivity type based on culture and } \\
\text { molecular testing }\end{array}$ \\
\cline { 2 - 6 } & Molecular and culture tests & Culture tests only & Molecular tests only & abs. & $\%(95 \%$ Cl) \\
\hline Sensitive & 478 & 207 & $673^{1)}$ & 1358 & $34.08(32.62-35.56)$ \\
\hline MDR & $1179^{2)}$ & 256 & 613 & 2048 & $51.39(49.84-52.94)$ \\
\hline Hr & $209^{3)}$ & 51 & 242 & 502 & $12.60(11.60-13.66)$ \\
\hline Other) & 42 & 23 & 12 & 77 & $1.93(1.55-2.41)$ \\
\hline Total & 1908 & 537 & 1540 & 3985 & 100 \\
\hline
\end{tabular}

Note: ${ }^{1}$ — including cases for which no mutations were detected in the genes associated with resistance to isoniazid, rifampicin and fluoroquinolones; ${ }^{2}$ — including $38 \mathrm{M}$. tuberculosis isolates for which no mutations in the rpoB gene (see the article) were detected; ${ }^{3}$ — including $29 \mathrm{M}$. tuberculosis isolates carrying mutant $r$ ro $B$ but having no resistance phenotype; ${ }^{4}$ - mono- or polyresistance to antituberculous drugs, excluding isoniazid.

Table 2. The frequency of detection of isoniazid-resistant M. tuberculosis in 2011-2018

\begin{tabular}{|l|c|c|c|}
\hline \multirow{2}{*}{ Year } & \multicolumn{3}{|c|}{ Number of M. tuberculosis isolates } \\
\cline { 2 - 4 } & Total isolates studied (abs.) & \multicolumn{2}{|c|}{ Hr isolates } \\
\cline { 2 - 4 } & 458 & 67 & $14.63(11.69-18.16)$ \\
\hline 2011 & 355 & 52 & $14.65(11.35-18.70)$ \\
\hline 2012 & 530 & 54 & $10.19(7.89-13.06)$ \\
\hline 2013 & 554 & 65 & $11.73(9.31-14.68)$ \\
\hline 2014 & 569 & 65 & $11.42(9.06-14.30)$ \\
\hline 2015 & 502 & 56 & $11.16(8.69-14.21)$ \\
\hline 2016 & 557 & 76 & $13.64(11.04-16.75)$ \\
\hline 2017 & 460 & 67 & $14.57(11.64-18.08)$ \\
\hline 2018 & & & \\
\hline
\end{tabular}


additional resistance (no necessarily MDR) to other anti-TB drugs 5.1 times more often than drug-susceptible strains. High occurrence rates of polyresistant strains demonstrated in our study (55\% of all $\mathrm{Hr}$-TB isolates) insensitive to $1-5$ drugs apart from isoniazid corroborate the possibility of drug resistance amplification in isoniazid-resistant $M$. tuberculosis.

Because first-line antituberculous drugs ethambutol and pyrazinamide are included in the standard chemotherapy regimen often prescribed empirically to newly diagnosed patients, it would be reasonable to expect high prevalence rates of $\mathrm{Hr} M$. tuberculosis strains additionally resistant to these 2 drugs. Indeed, resistance to ethambutol was detected in almost half of all polyresistant $M$. tuberculosis isolates analyzed in our study (70/143, 48.95\%; 95\% Cl: 40.89-57.06\%); pyrazinamide-resistant isolates were slightly rarer $(57 / 143$, 39.86\%; 95\% Cl: 32.20-48.05\%).

Polyresistant $M$. tuberculosis strains resistant to ethionamide (the second-line medication) were much more prevalent (80/143, 55.94\%; 95\% Cl: 47.76-63.82\%). This can ben explained by the fact that ethionamide is a structural analogue of isoniazid; it inhibits synthesis of mycolic acids, thereby disrupting the structure of the bacterial cell wall. Therefore, these two drugs may have common targets and genetic determinants of resistance $[5,13]$.

In general, the use of first-line drugs in the therapy of $\mathrm{Hr}$-TB leads to poor outcomes, including the lack of therapeutic effect, relapses, acquired MDR. Besides, standard empiric treatment of $\mathrm{Hr}$-TB can promote MDR-TB epidemics, especially in the regions where such TB forms are not rare [7]. At the same time, timely adjustments to the regimen based on results of isoniazid susceptibility testing and the use of modified regimens reinforce therapeutic success and reduce the risk of relapses [14-16].

In this light, 2 clinical studies should be mentioned that aimed to establish an association between mutations in M. tuberculosis and the efficacy of treatment of $\mathrm{Hr}$-TB with high doses of isoniazid [17, 18]. It is known that mutations in the katG gene, which dominated our sample, result in a high level of resistance to isoniazid whereas mutations in inhA, in a low level of resistance [5]. The studies revealed that therapy with isoniazid was effective when mycobacteria carried mutations in the inhA gene; katG mutations were associated with poor treatment outcomes $[17,18]$.

This emphasizes the need for effective regimens for the therapy of $\mathrm{Hr}$-TB $[8,19]$. Rapid drug susceptibility testing is critical. Molecular diagnostic methods are highly sensitive and rapid (1-2 days in comparison with weeks required for culture); they also provide valuable information about mutations carried by the strain and the level of isoniazid resistance [1]. Therefore, the demand for molecular methods in the diagnosis of TB and drug susceptibility testing is high. However, although tests based on allele specific PCR, bioarray technologies or DNA strips used in large TB healthcare centers expedite diagnosis, they impose strict requirements on staff qualifications and laboratory infrastructure.

Today, the only molecular test that can be deployed in any laboratory is Xpert MTB/RIF that utilizes the GeneXpert platform [20]. Unfortunately, this test can detect only genotypic resistance to rifampicin because these days all diagnostic procedures are largely focused on detecting MDR strains, which are resistant to rifampicin. Therefore, Xpert MTB/RIF cannot detect resistance to isoniazid in the strains that are sensitive to rifampicin (12\% of our isolates). In the absence of additional diagnostic tools, isoniazid resistance of such strains will never be revealed, leading to inadequate chemotherapy regimens and amplification of MDR. This indicates the need for a simple molecular test that is as convenient as Xpert MTB/RIF and can be used in any laboratory.

\section{CONCLUSIONS}

Isoniazid-resistant tuberculosis can be regarded as a potential predecessor of MDR disease. It is important to control the spread of primary resistance to isoniazid and prevent acquisition of further resistance. Our analysis revealed high prevalence

Table 3. Resistance spectra of isoniazid-resistant strains of $M$. tuberculosis

\begin{tabular}{|c|c|c|}
\hline \multirow{2}{*}{ Resistance spectra } & \multicolumn{2}{|c|}{ Number of $M$. tuberculosis strains } \\
\hline & abs. & $\%(95 \% \mathrm{Cl})$ \\
\hline Monoresistance $(\mathrm{H})$ & 117 & $45.00(39.07-51.08)$ \\
\hline $\begin{array}{l}\text { Polyresistance }(H+\text { other anti-TB } \\
\text { drugs except } R) \text { : }\end{array}$ & 143 & $55.00(48.95-61.05)$ \\
\hline To 2 anti-TB drugs: & 71 & $27.31(22.25-33.02)$ \\
\hline $\mathrm{HE}$ & 17 & \\
\hline $\mathrm{HZ}$ & 16 & \\
\hline H Eto & 31 & \\
\hline $\mathrm{H} \mathrm{Am}$ & 3 & \\
\hline H Cp & 1 & \\
\hline H Lfx & 3 & \\
\hline To 3 anti-TB drugs: & 36 & $13.85(10.17-18.57)$ \\
\hline HEZ & 9 & \\
\hline HE Eto & 13 & \\
\hline HE LfX & 1 & \\
\hline $\mathrm{HZ} \mathrm{Cp}$ & 1 & \\
\hline $\mathrm{HZ}$ Eto & 7 & \\
\hline H AmCp & 2 & \\
\hline H EtoAm & 3 & \\
\hline To 4 anti-TB drugs: & 21 & $8.08(5.34-12.03)$ \\
\hline HEZ Eto & 6 & \\
\hline HEZ Am & 1 & \\
\hline HEZ Lfx & 3 & \\
\hline HE AmCp & 2 & \\
\hline HE EtoAm & 4 & \\
\hline HE EtoLfx & 2 & \\
\hline HZ EtoCp & 1 & \\
\hline H EtoAmCp & 1 & \\
\hline H AmCpLfx & 1 & \\
\hline To 5 anti-TB drugs: & 12 & $4.62(2.66-7.89)$ \\
\hline HEZ EtoAm & 2 & \\
\hline HEZ EtoLfx & 4 & \\
\hline HEZ AmCp & 2 & \\
\hline HE EtoAmLfx & 1 & \\
\hline HZ AmCpLfx & 1 & \\
\hline HZ EtoAmLfx & 1 & \\
\hline H EtoAmCpLfx & 1 & \\
\hline To 6 anti-TB drugs: & 3 & $1.15(0.39-3.34)$ \\
\hline HEZ EtoAmCp & 2 & \\
\hline HEZ EtoAmLfx & 1 & \\
\hline Total & 260 & 100 \\
\hline
\end{tabular}

Note: in the lists of resistance spectra, first-line drugs are separated from secondline medications by a space character. 
Table 4. Isoniazid-resistant M. tuberculosis isolates with different combinations of mutations in the genes associated with isoniazid resistance

\begin{tabular}{|c|c|c|c|c|c|c|c|c|c|}
\hline \multirow{2}{*}{\multicolumn{3}{|c|}{$\begin{array}{ll}\text { Mutations in } a h p C \text { and } \operatorname{inh} A & \text { Mutations in katG }\end{array}$}} & \multirow{2}{*}{ Not detected } & \multicolumn{5}{|c|}{ At codon 351 , substitution of Ser to } & \multirow{2}{*}{ Total } \\
\hline & & & & Arg & Asn & Gly & $\operatorname{Thr}(1)^{*}$ & $\operatorname{Thr}(2)^{*}$ & \\
\hline \multicolumn{3}{|c|}{ No detected mutations in $a h p C$ or inhA } & - & $\begin{array}{c}4(0.89 \\
0.35-2.26)\end{array}$ & $\begin{array}{c}7(1.55 \\
0.75-3.17)\end{array}$ & $\begin{array}{c}3(0.67 \\
0.23-1.94)\end{array}$ & $\begin{array}{c}333(73.84 \\
69.59-77.68)\end{array}$ & $\begin{array}{c}1(0.22 \\
0.04-\end{array}$ & $\begin{array}{c}348 \text { (77.16; } \\
73.07-80.80)\end{array}$ \\
\hline \multirow{4}{*}{ SNP in $a h p C$ at position } & 6 & $\mathrm{G}->\mathrm{A}$ & - & - & - & - & $\begin{array}{c}1(0.22 \\
0.04-1.25)\end{array}$ & - & $\begin{array}{c}1(0.22 \\
0.04-1.25)\end{array}$ \\
\hline & \multirow{2}{*}{10} & $C->A$ & $\begin{array}{c}1(0.22 \\
0.04-1.25)\end{array}$ & - & - & - & - & - & $\begin{array}{c}1(0.22 \\
0.04-1.25)\end{array}$ \\
\hline & & $\mathrm{C} \rightarrow>\mathrm{T}$ & $\begin{array}{c}1(0.22 \\
0.04-1.25)\end{array}$ & - & - & - & $\begin{array}{c}1(0.22 \\
0.04-1.25)\end{array}$ & - & $\begin{array}{c}2(0.44 ; \\
0.12-1.60)\end{array}$ \\
\hline & 12 & $\mathrm{C}->\mathrm{T}$ & - & - & - & - & $\begin{array}{c}1(0.22 ; \\
0.04-1.25)\end{array}$ & - & $\begin{array}{c}1(0.22 \\
0.04-1.25)\end{array}$ \\
\hline \multirow{4}{*}{ SNP in inhA at position } & \multirow{2}{*}{8} & $\mathrm{~T} \rightarrow \mathrm{A}$ & $\begin{array}{c}2(0.44 \\
0.12-1.60)\end{array}$ & - & - & - & - & - & $\begin{array}{c}2(0.44 \\
0.12-1.60)\end{array}$ \\
\hline & & $\mathrm{T} \rightarrow \mathrm{G}$ & - & - & - & - & $\begin{array}{c}1(0.22 \\
0.04-1.25)\end{array}$ & - & $\begin{array}{c}1(0.22 \\
0.04-1.25)\end{array}$ \\
\hline & \multirow{2}{*}{15} & $\mathrm{C} \rightarrow \mathrm{G}$ & $\begin{array}{c}1 \text { (0.22; } \\
0.04-1.25)\end{array}$ & - & - & - & - & - & $\begin{array}{c}1(0.22 \\
0.04-1.25)\end{array}$ \\
\hline & & $\mathrm{C} \rightarrow \mathrm{T}$ & $\begin{array}{c}33(7.32 ; \\
5.26-10.10)\end{array}$ & - & - & $\begin{array}{c}1(0.22 ; \\
0.04-1.25)\end{array}$ & $\begin{array}{c}60(13.30 ; \\
10.48-16.75)\end{array}$ & - & $\begin{array}{c}94(20.84 ; \\
17.35-24.83)\end{array}$ \\
\hline \multicolumn{3}{|l|}{ Total } & $\begin{array}{c}38(8.43 \\
6.20-11.35)\end{array}$ & $\begin{array}{c}4(0.89 \\
0.35-2.26)\end{array}$ & $\begin{array}{c}7(1.55 \\
0.75-3.17)\end{array}$ & $\begin{array}{c}4(0.89 \\
0.35-2.26)\end{array}$ & $\begin{array}{c}397 \text { (88.03; } \\
84.70-90.71)\end{array}$ & $\begin{array}{c}1(0.22 \\
0.04-1.25)\end{array}$ & $451(100)$ \\
\hline
\end{tabular}

Note: SNPs occurring in only one gene associated with isoniazid resistance are highlighted in gray; other cells show combinations of $>1$ mutation. * Thr(1) represents the AGC->ACC substitution, Ser->Thr(2) represents the AGC->ACA substitution.

of $\mathrm{Hr}$-TB (over $12 \%$ of all analyzed cases) among isoniazidresistant rifampicin-susceptible $M$. tuberculosis strains isolated from patients with pulmonary TB. The majority of such isolates carried mutations causing strong resistance to isoniazid. Our findings indicate the importance of rapid testing for sensitivity to both rifampicin and isoniazid based on molecular-genetic methods. There is a need for simple point-of-care tests that do not impose high requirements on laboratory infrastructure.

\section{References}

1. Order of the Ministry of Health of the Russian Federation of 9 December 2014 «Ob utverzhdenii metodicheskikh rekomendatsiy po sovershenstvovaniyu diagnostiki i lecheniya tuberkuleza organov dykhaniya». Russian.

2. World Health Organization. Global tuberculosis report 2018 Geneva: World Health Organization; 2018. (WHO/CDS/TB/2018.20).

3. Nechaeva OB. TB situation Russiania. Tuberculosis and Lung Diseases. 2018; 96 (8): 15-24. Russian.

4. World Health Organization. WHO consolidated guidelines on drug-resistant tuberculosis treatment. Geneva: World Health Organization; 2019 (WHO/CDS/TB/2019.33).

5. Zhang $Y$, Yew WW. Mechanisms of drug resistance in Mycobacterium tuberculosis. Int J Tuberc Lung Dis. 2009; (13): 1320-30.

6. Sandgren A, Strong M, Muthukrishnan P, Weiner BK, Church GM, Murray MB. Tuberculosis drug resistance mutation database. PLoS Med. 2009; 6 (2): e2.

7. Gegia M, Winters N, Benedetti A, van Soolingen D, Menzies D. Treatment of isoniazid-resistant tuberculosis with first-line drugs: a systematic review and meta-analysis. Lancet Infect Dis. 2017; 17 (2): 223-34.

8. World Health Organization. WHO treatment guidelines for isoniazid-resistant tuberculosis: Supplement to the WHO treatment guidelines for drug-resistant tuberculosis. Geneva: World Health Organization; 2018 (WHO/CDS/TB/2018.7).

9. Siddiqi SH, Rusch-Gerdes S. MGIT procedure manual for BACTEC MGIT 960 TB System. 2006.

10. Chernousova LN, Smirnova TG, Larionova EE, i dr. Standartnyye operatsionnyye protsedury. Opredeleniye chuvstvitel'nosti mikobakteriy tuberkuleza k protivotuberkuleznym preparatam vtorogo ryada s ispol'zovaniyem sistemy BACTEC MGIT 960/320. Moscow, 2015. Russian.
11. Jenkins HE, Zignol M, Cohen T. Quantifying the Burden and Trends of Isoniazid Resistant Tuberculosis, 1994-2009. PLoS ONE. 2011; 6 (7): e22927.

12. Menzies D, Benedetti A, Paydar A, Martin I, Royce S, Pai M, et al. Effect of duration and intermittency of rifampin on tuberculosis treatment outcomes: a systematic review and meta-analysis. PLoS Med. 2009; 6 (9): e1000146.

13. Jeon CY, Hwang SH, Min JH, Prevots DR, Goldfeder LC, Lee H, et al. Extensively drug-resistant tuberculosis in South Korea: risk factors and treatment outcomes among patients at a tertiary referral hospital. Clin Infect Dis. 2008; (46): 42-9.

14. Bang D, Andersen PH, Andersen AB, Thomsen VØ. Isoniazidresistant tuberculosis in Denmark: mutations, transmission and treatment outcome. J Infect. 2010; 60 (6): 452-7.

15. Salindri AD, Sales RF, DiMiceli L, Schechter MC, Kempker RR, Magee MJ. Isoniazid monoresistance and rate of culture conversion among patients in the state of Georgia with confirmed tuberculosis, 2009-2014. Ann Am Thorac Soc. 2018; 15 (3): 331-40.

16. Cattamanchi A, Dantes RB, Metcalfe JZ, Jarlsberg LG, Grinsdale J, Kawamura LM, et al. Clinical characteristics and treatment outcomes of patients with isoniazid-monoresistant tuberculosis. Clin Infect Dis. 2009; 48 (2): 179-85.

17. Tolani MP, D'souza DT, Mistry NF. Drug resistance mutations and heteroresistance detected using the GenoType MTBDRplus assay and their implication for treatment outcomes in patients from Mumbai, India. BMC Infect Dis. 2012; (12): 9.

18. Huyen MN, Cobelens FG, Buu TN, Lan NT, Dung NH, Kremer K, et al. Epidemiology of isoniazid resistance mutations and their effect on tuberculosis treatment outcomes. Antimicrob Agents Chemother. 2013; 57 (8): 3620-7.

19. Stagg HR, Harris RJ, Hatherell HA, Obach D, Zhao H, Tsuchiya N, et 
al. What are the most efficacious treatment regimens for isoniazidresistant tuberculosis? A systematic review and network metaanalysis. Thorax. 2016; 71 (10): 940-9.

20. World Health Organization. WHO meeting report of a technical expert consultation: non-inferiority analysis of Xpert MTB/RIF Ultra compared to Xpert MTB/RIF. Geneva: World Health Organization; 2017. WHO/HTM/TB/2017.04. Available from: https://www.who. int/tb/publications/2017/XpertUltra/en/. Accessed: 18 May 2019.

\section{Литература}

1. Приказ Министерства здравоохранения Российской Федерации от 29 декабря 2014 № 951 «Об утверждении методических рекомендаций по совершенствованию диагностики и лечения туберкулеза органов дыхания».

2. World Health Organization. Global tuberculosis report 2018. Geneva: World Health Organization; 2018. (WHO/CDS/ TB/2018.20)

3. Нечаева О. Б. Эпидемическая ситуация по туберкулезу в России. Туберкулез и болезни легких. 2018; 96 (8): 15-24.

4. World Health Organization. WHO consolidated guidelines on drug-resistant tuberculosis treatment. Geneva: World Health Organization; 2019 (WHO/CDS/TB/2019.33).

5. Zhang $Y$, Yew WW. Mechanisms of drug resistance in Mycobacterium tuberculosis. Int J Tuberc Lung Dis. 2009; (13): 1320-30.

6. Sandgren A, Strong M, Muthukrishnan P, Weiner BK, Church GM, Murray MB. Tuberculosis drug resistance mutation database. PLoS Med. 2009; 6 (2): e2.

7. Gegia M, Winters N, Benedetti A, van Soolingen D, Menzies D. Treatment of isoniazid-resistant tuberculosis with first-line drugs: a systematic review and meta-analysis. Lancet Infect Dis. 2017; 17 (2): 223-34.

8. World Health Organization. WHO treatment guidelines for isoniazid-resistant tuberculosis: Supplement to the WHO treatment guidelines for drug-resistant tuberculosis. Geneva: World Health Organization; 2018 (WHO/CDS/TB/2018.7).

9. Siddiqi SH, Rusch-Gerdes S. MGIT procedure manual for BACTEC MGIT 960 TB System. 2006

10. Черноусова Л. Н., Смирнова Т. Г., Ларионова Е. Е., и др. Стандартные операционные процедуры. Определение чувствительности микобактерий туберкулеза к противотуберкулезным препаратам второго ряда с использованием системы ВАСTEC MGIT 960/320. Москва, 2015.

11. Jenkins HE, Zignol M, Cohen T. Quantifying the Burden and Trends of Isoniazid Resistant Tuberculosis, 1994-2009. PLoS ONE. 2011; 6 (7): e22927.

12. Menzies D, Benedetti A, Paydar A, Martin I, Royce S, Pai M, et al.

Effect of duration and intermittency of rifampin on tuberculosis treatment outcomes: a systematic review and meta-analysis. PLoS Med. 2009; 6 (9): e1000146.

13. Jeon CY, Hwang SH, Min JH, Prevots DR, Goldfeder LC, Lee H, et al. Extensively drug-resistant tuberculosis in South Korea: risk factors and treatment outcomes among patients at a tertiary referral hospital. Clin Infect Dis. 2008; (46): 42-9.

14. Bang D, Andersen PH, Andersen AB, Thomsen VØ. Isoniazidresistant tuberculosis in Denmark: mutations, transmission and treatment outcome. J Infect. 2010; 60 (6): 452-7.

15. Salindri AD, Sales RF, DiMiceli L, Schechter MC, Kempker RR, Magee MJ. Isoniazid monoresistance and rate of culture conversion among patients in the state of Georgia with confirmed tuberculosis, 2009-2014. Ann Am Thorac Soc. 2018; 15 (3): 331-40.

16. Cattamanchi A, Dantes RB, Metcalfe JZ, Jarlsberg LG, Grinsdale J, Kawamura LM, et al. Clinical characteristics and treatment outcomes of patients with isoniazid-monoresistant tuberculosis. Clin Infect Dis. 2009; 48 (2): 179-85.

17. Tolani MP, D'souza DT, Mistry NF. Drug resistance mutations and heteroresistance detected using the GenoType MTBDRplus assay and their implication for treatment outcomes in patients from Mumbai, India. BMC Infect Dis. 2012; (12): 9.

18. Huyen MN, Cobelens FG, Buu TN, Lan NT, Dung NH, Kremer K, et al. Epidemiology of isoniazid resistance mutations and their effect on tuberculosis treatment outcomes. Antimicrob Agents Chemother. 2013; 57 (8): 3620-7.

19. Stagg HR, Harris RJ, Hatherell HA, Obach D, Zhao H, Tsuchiya N, et al. What are the most efficacious treatment regimens for isoniazidresistant tuberculosis? A systematic review and network metaanalysis. Thorax. 2016; 71 (10): 940-9.

20. World Health Organization. WHO meeting report of a technical expert consultation: non-inferiority analysis of Xpert MTB/RIF Ultra compared to Xpert MTB/RIF. Geneva: World Health Organization; 2017. WHO/HTM/TB/2017.04. Available from: https://www.who. int/tb/publications/2017/XpertUltra/en/. Accessed: 18 May 2019. 